コーヒー飲料による糖代謝マーカーの改善に関する臨床研究

一唾液中カフェイン濃度測定の妥当性一

岡田知子, ${ }^{a}$ 小林大介, ${ }^{a}$ 古野純典, ${ }^{b}$ 島添隆雄 $*, a$

\title{
Clinical Research on Improvement of Glucose Metabolic Marker Level by Coffee Drinking - Validity of Saliva Caffeine Concentration Measurement-
}

\author{
Tomoko OKADA, ${ }^{a}$ Daisuke KobAYASHI, ${ }^{a}$ Suminori Kono,${ }^{b}$ and Takao SHIMAZOE ${ }^{*, a}$ \\ ${ }^{a}$ Department of Clinical Pharmacy and Pharmaceutical care, Graduate School of Pharmaceutucal Sciences, \\ and ${ }^{b}$ Department of Preventive Medicine, Graduate School of Medical Sciences, Kyushu University, \\ 3-1-1 Maidashi, Higashi-ku, Fukuoka 812-8582, Japan
}

(Received November 17, 2009)

\begin{abstract}
We measured both serum and saliva caffeine concentration using HPLC and assessed the correlation between them in volunteers with mild obesity. Significant correlation was shown between saliva and serum caffeine concentration. It may be necessary to measure caffeine metabolite concentration because its metabolites may also have an improving effect of glucose metabolism. In summary, we found that saliva caffeine concentration measurement was useful to assess caffeine intake level. Moreover, it will be helpful to know whether caffeine has an improving effect of glucose metabolism.
\end{abstract}

Key words_— caffeine; glucose metabolism; HPLC; saliva; serum

\section{1.はじめに}

インスリンは糖代謝の重要なホルモンである.イ ンスリンの作用不足によって，糖代謝異常をきた す。この糖代謝異常に付随して起こる三大合併症が 死亡率に深く係わっている，糖尿病の診断に利用さ れる 75g-経ロブドウ糖負荷試験（Oral glucose tolerance test；OGTT）では，糖代謝異常及び異常空腹 時血糖が設定され, 特に冠動脈疾患の危険性も指摘 される，そのほかに，糖尿病の発症には体質の違い が反映すると言われている，2 型糖尿病は，肥満及 び肥満の既往者に多いと指摘されている。したがつ

て，2 型糖尿病を発症していない中等度肥満者にお いては，生活習慣の見直しが必要であると考えられ る.

糖尿病は, 嗜好品との関係について様々な報告が なされている. ${ }^{1)}$ 特にコーヒーとの関連について

$a$ 九州大学大学院薬学研究院臨床育薬学分野, $b$ 同院医 学研究院予防医学分野 (T812-8582 福岡市東区馬出 3 $-1-1)$

*e-mail: shimazoe@phar.kyushu-u.ac.jp

本総説は, 日本薬学会第 129 年会シンポジウム GS5 で 発表したものを中心に記述したものである.
は，世界各地で研究されてきた. ${ }^{2)}$ 多くの疫学研究 の結果から，コーヒ一飲用が 2 型糖尿病に予防的で あることはほぼ間違いないと考えられている. ${ }^{3)} ま$ た，コーヒー飲用者では $75 \mathrm{~g}-$ OGTT で診断される 耐糖能障害を示す者が少なく, ${ }^{4)}$ インスリン感受性 も良好であることが指摘されている。 レギュラー・ コーヒーとデカフェ・コーヒーを区別して，カフェ インの 2 型糖尿病との関連について検討された報告

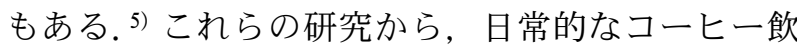
用による耐糖能やインスリン感受性の改善を長期の 介入試験によって確認することが重要である，そこ で，われわれは，コーヒー 1 日 5 杯飲用が中等度肥 満者の糖代謝マーカー及び血清炎症マーカーを改善 するか否かを調べるために，無作為化比較対照試験 （Randomized Controlled Trial; RCT）を開始した. 介入研究においては，コンプライアンスの確認は極 めて重要であり, 本研究では血清並びに唾液中のカ フェイン濃度は HPLC を用いて測定した。

本研究計画は, 九州大学大学院医学研究院の倫理 委員会で承認を受けた。対象者は，新聞記事や広告 なぞを通じて公募された．Table 1 に対象者の選定 
Table 1. Eligible Criteria for the Entry of this Study

(1) Men aged 40-64 years

(2) Body mass index: $25-30 \mathrm{~kg} / \mathrm{m}^{2}$

(3) Having no disease under medication and no life-limiting disease

(4) No history of gastrectomy

(5) Recorded fasting plasma glucose concentration of 100$140 \mathrm{mg} / \mathrm{dl}$ in the past year or $90-140 \mathrm{mg} / \mathrm{dl}$ at the screening when no measurement in the past year

(6) Being able to drink coffee, but not drinking coffee daily

(7) Being able to keep a current way of living in the next 18 weeks

基準を示した，選定基準をすべて満たしたものにお いて，インフォームド・コンセントを書面で取得し た。本試験には観察期間を 2 週間設定し，その間対 象者（27 名）にはカフェインの摂取を禁じた。試 験期間は 16 週間と設定し，レギュラー・インスタ ントコーヒー (11 名), デカフェ・インスタント コーヒー（7 名）あるいは水（9名）を飲用しても らった。特に，コーヒー飲用群には，インスタント コーヒー並びに同一規格の小さじ（1 杯が粉末 1.2$1.3 \mathrm{~g}$ になることを確認済み）を 2 本配布し 1 日 5 杯飲用してもらった。試験開始より 0,8 , 及び 16 週に検查と採血, そして，0-8 週及び 9-16 週には 対象者の自宅に訪れ，唾液の採取を行った。糖代謝 の評価のためには, 75g-OGTT を行った。また, 腹 囲及び体重の変化も検討した. これらの測定は, 九 州大学大学院医学研究院予防医学分野によって遂行 された.

\section{2. 生体試料中カフェインの定量に関する検討}

近年, 体内薬物濃度の推定に唾液が利用されてい る. 唾液中のカフェイン濃度は, 組織中のカフェイ ン濃度を反映するものとして期待される．採血に比 へ，唾液の採取は対象者にとって非侵襲的である. 本研究では, 約 $150 \mathrm{ml}$ の水で口を漱いだ後, 口腔 内に綿球をおいた唾液の採取方法によって, 口腔内 のコーヒー中カフェインの残存がなくなるように工 夫した.

血清並びに唾液中カフェイン濃度に関して, HPLC を用いて検討した. ${ }^{6}$ ) 血清中のカフェイン濃 度の測定において, HPLC は熊本大学の河内山氏 らの方法を一部改修して行った。同様にして, 唾液 中のカフェイン濃度の測定を行った。本法において,

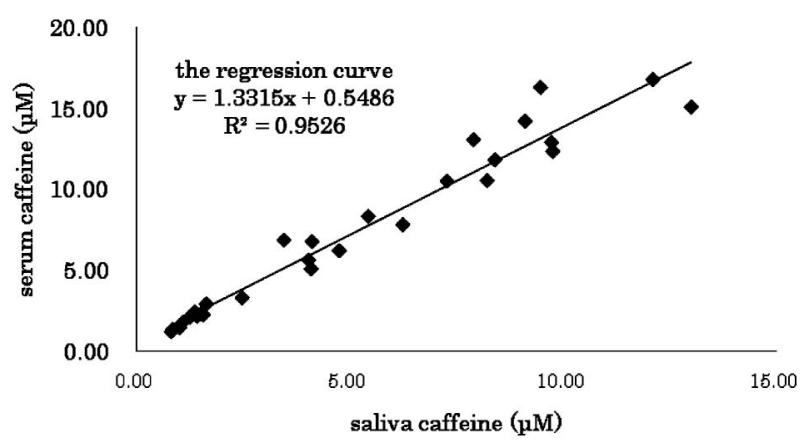

Fig. 1. Correlation between Serum and Saliva Caffeine Concentration

$n=28$.

1-100 $\mu \mathrm{M}$ の濃度範囲でカフェインの定量が可能で あった. 一方，コーヒー中のカフェインの代謝物も， HPLC により測定ができる。主な代謝物として, パラキサンチン，テオフィリン及びテオブロミンが ある.これらの代謝物に関しても， S/P 比によい相 関があることが報告されており,7) 今後はこれらの 時間推移についても，更なる実験が必要であろう。

次に, 対象者の 0,8 , 及び 16 週の生体試料中力 フェインを定量した。血清中並びに唾液中カフェイ ン濃度の相関は, Fig. 1 に示した。 血清中カフェイ ン濃度に対する唾液中カフェイン濃度の比は, 0.67 $( \pm 0.08) \quad(n=28)$ であり, 統計学的に強い相関を 示した $(\mathrm{r}=0.97, p<0.001)$ ．これらを合わせて考 えると, 血液の代替生体試料として唾液の安全性と 有用性が支持されると思われた.

\section{3. コーヒー飲用コンプライアンスの検討}

今回の試験では，レギュラー・インスタントコー ヒー群, デカフェ・インスタントコーヒー群, 非 コーヒー（水）群の 3 群を設定し，コーヒー飲用の コンプライアンスを唾液中カフェイン濃度から評価 した。 コンプライアンスの不良者は，デカフェ・ コーヒー群 1 名及び非コーヒー群 2 名であった。こ れらの者ではカフェイン濃度が $1 \mu \mathrm{M}$ を超えてい た. 介入期間 0-8 週及び 9-16 週は, 対象者の自宅

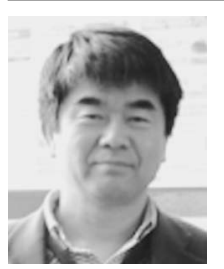

島添隆雄
九州大学大学院薬学研究院臨床育薬学 分野准教授. 1958 年生まれ. 九州大学 大学院薬学研究科博士課程終了. 1988 年国立病院九州がんセンター臨床研究 部研究員. 1995 年より現職. 2005 年九 州大学大学院薬学研究院薬剂疫学分野 准教授.この間 Columbia 大学留学. 薬学部 6 年制教育に力を入れている. 
に突然赴き，唾液の採取を行つた。このため，唾液 中カフェイン濃度から，コーヒーの飲用状況がより 適切に判断できる. しかしながら, 体内のカフェイ ンの消失によって，濃度が異なることも予想される.

本研究により, 唾液中カフェイン濃度測定によ り, レギュラー・コーヒー群のコンプライアンスを 評価できることが確認された。 また，カフェイン濃 度別にレギュラー・コーヒー飲用の糖代謝マーカー への影響を検討する必要性がある.

\section{4. おわりに}

コーヒー飲用のコンプライアンスは，唾液中カフ エイン濃度の測定により評価でき, 血中カフェイン 濃度測定に比べてより安全で簡便である，近年，力 フェイン及びその代謝物の肥満に対する作用につい て様々な議論がなされている. ${ }^{8)}$ 肥満は薬物体内動 態変動の要因の一つであり, 著しく体重が増加した 場合, 薬の分布容積や肝, 腎などの機能と血流量の 変化をもたらす。体脂肪の増加は，カフェインの半 減期の延長及び分布容積の増加を生じさせるが，全 身クリアランスには影響がない。一方，カフェイン は CYP（cytochrome P450）1A2 によって代謝を受 ける。CYP1A2 はその遺伝子多型が報告されてい る. 9,10) 今回, 遺伝子研究は行わなかったが，この ような遺伝子の相違によるカフェイン代謝の違い が，糖代謝に影響を与える可能性も否定できない. 今後は, カフェイン代謝物の測定も重要であると考 えられる。

\section{REFERENCES}

1) Honjo S., Kono S., Coleman M. P., Shinchi K., Sakurai Y., Todoroki I., Umeda T., Wakabayashi K., Imanishi K., Nishikawa H., Ogawa S., Katsurada M., Nakagawa K., Yoshizawa N., J. Clin. Epidemiol., 54, 823829 (2001).

2) Larsson S. C., Wolk A., Gastroenterology, 132, 1740-1745 (2007).

3) Van Dam R. M., Manson J. E., Willett W. C., Hu F. B., Diabetes Care, 29, 398-403 (2006) .

4) Yamaji T., Mizoue T., Tanabe S., Ogawa S., Yamaguchi K., Shimizu E., Mineshita M., Kono S., Diabetologia, 47, 2145-2151 (2004).

5) Van Dam R. M., Hu F. B., JAMA, 294, 97104 (2005).

6) Akinyinka O. O., Sowunmi A., Honeywell R., Renwick A. G., Eur. J. Clin. Pharmacol., 56, 159-165 (2000).

7) Tang-Liu D. D., Williams R. L., Riegelman S., Clin. Pharmacol. Ther., 31, 358-369 (1982).

8) Zahorska-Markiewicz B., Waluga M., Zielinski M., Klin M., Int. J. Clin. Pharmacol. Ther., 34, 393-395 (1996).

9) Koch J. P., ten Tusscher G. W., Koppe J. G., Guchelaar H. J., J. Chromatogr. B, 385, 267274 (1987).

10) Cornelis M. C., El-Sohemy A., Kabagambe E. K., Campos H., JAMA, 295, 1135-1141 (2006). 